\title{
Calciphylaxis cutis
}

INSERM

\section{Source}

INSERM. (1999). Orphanet: an online rare disease and orphan drug data base.

Calciphylaxis cutis. ORPHA:280065

Calciphylaxis cutis is a life-threatening syndrome characterized by progressive and painful skin ulcerations associated with media calcification of medium-size and small cutaneous arterial vessels. It affects mainly patients on dialysis or after renal transplantation. 